\title{
NEW HORIZONS OF ISLAMIC STUDIES THROUGH SOCIO-CULTURAL HERMENEUTICS
}

\author{
M. Amin Abdullah
}

The Rector of LAIN Sunan Kalijaga Yogyakarta

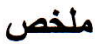

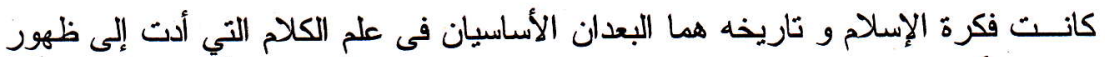

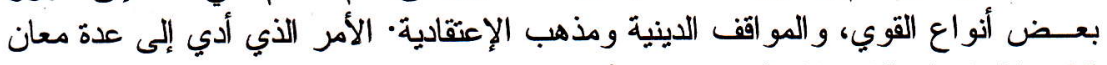

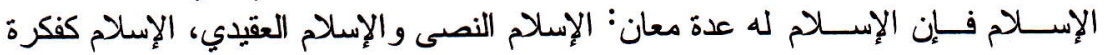

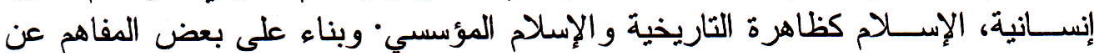

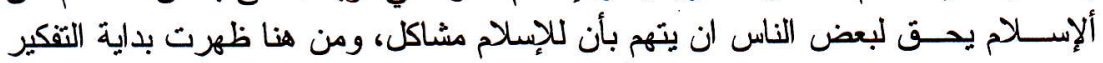

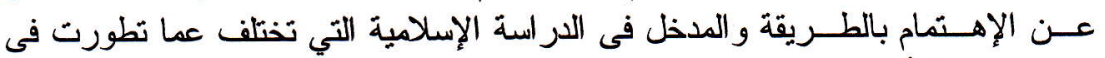

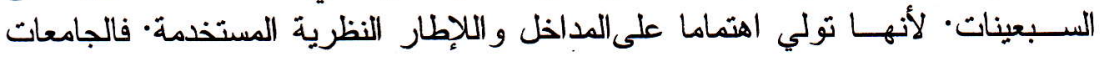

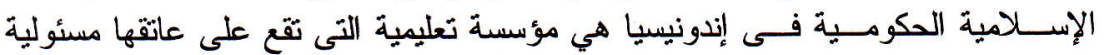

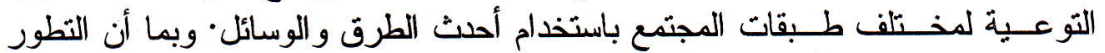

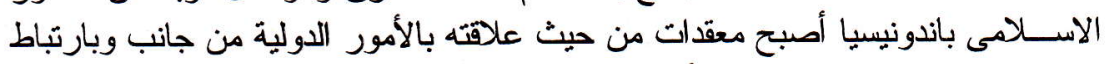

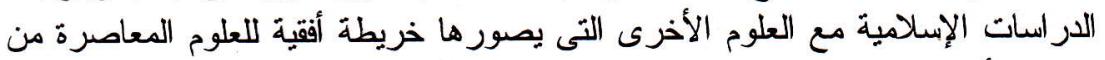

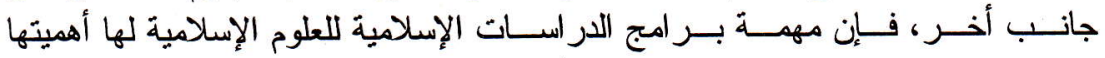

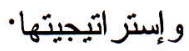

\section{Abstrak}

Pemikiran dan sejarah Islam adalab dua dimensi pokok Islam teologis yang telah mendorong munculnya berbagai kekuatan, sikap keagamaan dan ideologis. Akbirnya, Islam mengandung beberapa makna: Islam sebagai teks (naskab) dan teologi/kalam; Islam sebagai pemikiran kemanusiaan; Islam sebagai sejarab, dan Islam sebagai suatu "lembaga". Dengan berbagai pengertian Islam di dalam benak para pengamat sosial keagamaan tersebut, lalu orang sah menyebut atau mengangkat isu babwa Islam memang "problematik". Dari sinilab bermula muncul pentingnya metode dan pendekatan dalam studi atau kajian keislaman. Metode ini berbeda dengan yang sudah dikembangkan tabun 
70-an, karena metode ini lebih menekankan corak pendekatan (approacb) berikut kerangka teori yang digunakan. UIN/LAIN/STAIN (Universitas Islam Negeri/Institut Agama Islam Negeri/Sekolab Tinggi Agama Islam Negeri) adalah lembaga akademik yang paling bertanggungjawab di tanah air untuk menjelaskan kepada masyarakat luas dengan menggunakan metode dan pendekatan mutakbir yang dapat dipertanggung-jawabkan. Mengingat kompleksnya perkembangan Islam di tanah air dalam bubungannya dengan dunia internasional serta pertemuan dan pertautan keilmuan Islamic Studies dengan ilmu-ilmu lain yang tergambar dalam peta borizon keilmuan Islamic Studies kontemporer, maka fungsi pendidikan pada level Strata satu, dan lebihlebib Pascasarjana Studi Keislaman, adalah sangat penting dan strategis.

... "having raised the question of international relations, politics, and economics, that does not mean that scholars of religion must become economists or political scientists. However, the study of religion will suffer if its insights do not take cognizance of how the discourses of politics, economics, and culture impact on the performance of religion and viceversa"

(Ebrahim Moosa)

Keywords: theoretical framework, epistemology, philosophical paradigm, post-positivistic era

\section{A. Introduction}

In the view of Ibrähim M. Abu Rābi', there are at least several opinions that must be considered when observing and discussing "Islam" academically in the current era:

1. The Philosophical/ideological base. Islam has become a philosophical/ideological issue in the modern Arab world and in Islamic thinking in general. Some people discuss elite Islam, that is official Islam, whereas others discuss popular or oppositional Islam. These two observational positions agree that Islam can be either a passive or revolutionary power in society. Moreover those who are more daring opine that the concept of Islam as a divine revelation can no longer be maintained, and that what is now called Islam is none other than what people, groups or communities do in the name of Islam. Islam can be "used" as tool for achieving progress or as a tool 
for justifying economic and social discrepancies. In other words, according to this view, Islam cannot be held up as a "holy" entity. Practically speaking, some may say that Islam has been infiltrated by more than one understanding or definition.

2. The Theological base. On a theological level, Islam has an open-ended meaning, from belief in one God to theological connectedness to all the divine revelation that preceded it, while it can also be understood simply as "surrendering oneself to one God". In other words, one can research and test the theological base of Islam from the perspective of religious history, especially Christianity and Judaism, or from the perspective of inclusive theology, that is The Oneness of God.

3. The level of the text (nas). The text (nas) is the main core of Islamic culture. In the general opinion of experts in Islamic laws, both the alQur'an and the al-Hadith are the textual bases of Islam, and these also constitute the main theological bases of Islam. As such, it is true to say that from the beginning of the history of Islam there has been a dialectic connection between the texts and the human history and between the texts and human thinking. In other words, there has been a complex fusion between History and Muslim thinking, between that which is human, and that which is divine, or between religious writings and socio-economic and political factors.

4. The level of Anthropological Reality. There are also those who present Islam as a comprehensive anthropological reality. Indeed it is true that Islam has a normative side. Nevertheless, in its historical development Islam has supported the birth of complex cultural, social, literary, philosophical and political traditions, and up till now still shapes the outlook of Muslim societies. Islam has become an interesting issue in matters connected to power and social and political organizations. It is important to note that various intellectual and political movements have interpreted this tradition differently. This means that this tradition can be interpreted as a passive or a revolutionary power. ${ }^{1}$

'Ibrāhim M. Abu Rābi’, “A post-September 11 Critical Assessment of Modern Islamic History" in Ian Markham and Ibrāhim M. Abu Rābi' (Ed.), 11 September. Religious Perspective on the Causes and Consequences (Oxford: Oneworld Publications, 2002), pp. 30-31. 
Based on this, observers then state that Islamic Thought and Islamic History, two core dimensions surrounding the essence of Islamic Theology, have encouraged the emergence of a variety of religious and ideological powers and attitudes, which take the al-Qur'an and al-Sunnah as their starting point. Perhaps it is beneficial if here we are reminded of the various meanings that accompany Islam: Islam as a text (nas) and theology/the word of God; Islam as human thinking; Islam as history and Islam as one of many institutions. With these various understandings of Islam in the minds of socio-religious observers, it is quite valid for people to suggest that Islam is indeed 'problematic'.

It is from here that the importance of "method" (process and procedure to obtain data) and "approach" (the way of thinking) emerges in Islamic studies. This started to be explored in the 1970s by Mukti Ali, and is still relevant up till now given the complex problems within "Islam" that have emerged recently. In the era of Mukti Ali, the stress was more on "method", while in the current era 25 years later we focus on method but also on the form of approach in the theoretical framework that is used. UIN/IAIN/STAIN (the State Islamic University/ the State Institute of Islamic Studies/the State College for Islamic Studies) are the academic institutions in Indonesia with the greatest responsibility to explain to the general public using the most up-to-date and reliable methods and approaches (compare with the attachments at the end of this paper). The academic language used by UIN/IAIN/STAIN (the State Islamic University/the State Institute of Islamic Studies/the State College for Islamic Studies) also must not be exclusive, where it can only be understood by their own circle. Rather it must be inclusive, and able to be understood by the disciplines of social studies, humanities and religious studies that are generally studied in the modern universities around us.

\section{B. The Academic Concern of Scholars of Contemporary Islamic Studies: Continuity and Change between the "Great Tradition" and "Little Tradition" in Islamic Studies.}

Several contemporary Muslim thinkers, including the late Fazlur Rahman, Muhammed Arkoun, Ḥassan Hanafi, Muhammad Shahrūr, 
Abdullāhi Ahmed al-Nā'im, Riffat Hassān, and Fậima Mernisi draw our attention to the academic paradigms of Islamic Studies, especially the academic paradigms of figh (Islamic jurisprudence) and kalam (Islamic theology). Fiqh, with its implications for the perspectives and social institutions within Islamic life, is considered too rigid, and accordingly not responsive enough to the challenges and demands posed by modern life, especially in matters connected to budüd, human rights, public law, women, and views about non-Muslims. Although the door to interpretation has been opened - and many also believe that in fact it was never closed, - it still remains 'Ulum al-din, and especially the sciences of figh and kaläm still do not dare to approach, let alone enter that door that is always open. Explicitly, the science of $f i q h$, which influences the perspective and social order of institutions in Muslim societies, holds back from touching on or entering into dialogue with the new sciences that appeared in the 18th and 19th centuries like anthropology, sociology, cultural studies, psychology, philosophy and so on. ${ }^{2}$

Richard C. Martin, an expert on Islamic Studies from Arizona University with his book Approaches to Islam in Religious Studies ${ }^{3}$ and Muhammed Arkoun from The Sorbonne, Paris with his book Tarikbiyyah al-Fiker al-'Araby aI-Islamy ${ }^{4}$, as well as Naṣr Hamid Abu Zaid from Egypt with his book Naqd al-Khitäb al-Diniy ${ }^{5}$ strongly desire to open up the possibility of contact and a direct meeting between the traditional perspectives in Islamic Studies, or what Imām Abu Hamīd al-Ghazzāli calls 'Ulum al-din of the 10th and 11th centuries', and contemporary Religious Studies that utilizes the theoretical frameworks, methodologies

${ }^{2}$ Some of the academic concern of scholars of Islamic Studies is compiled effectively in Charles Kurzman (Ed.), Liberal Islam A Sourcebook (New York: Oxford University Press, 1988). This analysis has certainly been too generalized. Several Indonesian Muslim scholars have started to realize the importance of this issue so that they are encouraging the emergence of the lecture subject 'the Social History of Islamic Law'. See further, M. Atho Mudzhar, "Social History Approach to Islamic Law", al-Jami'ah, No. 61/1998, pp. 87-88.

${ }^{3}$ Richard C. Martin (Ed.), Approaches to Islam in Religious Studies (Tucson: The University of Arizona Press, 1985), especially pp. 1-18.

${ }^{4}$ Muhammed Arkoun, Tarikhiyyah al-Fikr al-'Araby al-'Islämy (Libanon: Markaz al Inma' al-Qaumy, 1986), pp. 51-63

${ }^{5}$ Naṣr Hạamid Abu Zaid, Naqd al-Khitāab, al-Diniy (Qahira, Sina li al-Nashr, 1994). 
and approaches of the social sciences and humanities that developed in the 18th and 19th centuries. Dialogue between these two camps has been pioneered by contemporary Muslim scholars, some of whom were mentioned above. ${ }^{6}$

When these two academic traditions meet and dialogue, the theoretical frameworks, methods, approaches, epistemology used also needs to change. Fazlur Rahman considers that it is no longer sufficient to use the theories of $f i q b /$ Islamic jurisprudence that are popular amongst usuitiyyun and jurists, namely "qat'ivyat" and "zanniyyat". He modified these with the "double movement" theory, in a relational-intrinsic formula between the "ideal moral" area of the al-Qur'-an and the "legal specific" area of fiqh. ${ }^{7}$ Muhammed Arkoun questions the disappearance of the "tärikhiyyat" (historicity) from the sciences of figh and kalam. He explicitly questions the validity of the theories of kalam, and figh and certainly also tasawnuf, which was compiled many centuries ago, being taught continually as something eternal in the current era where the problems and challenges are continually changing and not like they once were. I have quoted the following excerpt of Arkoun's opinion:

... the experts of fiqh who are also theologians (Mutakallimun) don't know about that. They practice a limited type of interpretation and make a certain methodology, that is Islamic jurisprudence and rules. These two factors have changed the discourse of the al-Qur'an, which has a mythical-metaphorical meaning open to various meanings and understandings, into a standard and rigid discourse and.... have resulted in the abandonment of the historicity of religious-ethical norms and the laws of Islamic jurisprudence. So it is as if the norms and laws of figh are outside of history and outside social circumstance; it has become holy: it may not be touched or discussed...The experts of Islamic jurisprudence have changed the socio-historical phenomena that are temporal and are based on the era into a type of ideal standard and holy transcendent law that cannot be changed and cannot be replaced. All forms of

"For a comparison see "Kata Pengantar" written by the author in the Indonesian translation of Richard C. Martin's book Pendekatan Kajian Islam dalam Studi Agama (Surakarta: Muhammadiyah University Press, 2001), pp. iii-ix.

${ }^{7}$ Fazlur Rahman, Islam and Modernity: Transformation of an Intellectual Tradition (Chicago and London: The University of Chicago Press, 1982) especially pp.13-42. 
establishment and practices born from these laws and standards then take on an order of sacrality (ardiyyab) and Godly transcendence which separates them from their foundation or from biological, social, economic and ideological circumstances. In this way, historicity is neglected and thrown out by the established orthodoxy. This situation has continued until today, and in fact the abandonment of historicity has increased as time goes by. ${ }^{8}$

Al-Nä'im questions the naskh-mansükh theory which has been used by scholars of Islamic jurisprudence up till now by putting forward the thesis that the Makkiyyah verses which put more weight on the universal humanitarian values cannot just be erased by the Madaniyyah verses which are oriented toward more particular and specific problems. ${ }^{9}$ Meanwhile, Fațima Mernissi, Riffat Hassan, Amina Wadud-Muhsin and many others question the validity of the misogynic Hadith ${ }^{10}$ by using the framework of gender analysis. If their analyses are correct and become widely accepted by academics and practitioners in contemporary Muslim society, then the impact for the science of Islamic law and fiqh or 'Ulum al-din in its classical paradigm in general will be very wide indeed. The works of Muhammad Shahrür like al-Kitäb wa al-Qur'an, which introduces his theory on "ḅudüd" also questions the accuracy of the analysis and scientific framework of classical Islam if it is applied intact in the contemporary era. ${ }^{11}$ All of this is intended only to "develop" or enrich the discourse of scientific analysis and research within Diräsat Islamiyyah (Islamic Studies), especially in terms of fiqh and kalam, because the way of thinking, worship in the widest sense, socializing, dialoguing, relating with others, living in communities, nations and states in the 20th and even more so in the 21 st centuries is completely different from what it was in the 10th century when the foundation and formulation of Islamic science 'ast tadwin was made. Terms that have

${ }^{8}$ Muhammed Arkoun, Al-Isläm: al-Akblāq wa al-Siyasab (Beirut: Markaz al-Inma' alQaumi, 1986), pp. 172-173. Translated into English by the writer.

${ }^{9}$ Abdullāhi Ahmed An-Na'im, Toward an Islamic Reformation: Civil Liberties, Human Rights and International Law (New York: Syracuse University Press, 1990).

${ }^{10}$ Fatima Mernissi, Beyond the Veil: Male-Female Dynamics in the Modern Muslim Society (Bloomington: Indiana University Press, 1987); Riffat Hassan and Fațima Mernissi, Setara di Hadapan Allah, translated by the LSPPA team, $2^{\text {nd }}$ edition (Yogyakarta: Lembaga Studi Pengembangan Perempuan dan Anak [LSPPA]), 1996.

${ }^{11}$ Muhammad Shahrūr, Al-Kitāb wa al-Qur'an: Qira'ah Mu'asirah (Dimasq, 1990). 
recently emerged along with the developing philosophical paradigm concern the desire, and even demand to humanize Islamic law, and even more widely to humanize Islamic sciences ${ }^{12}$, which is different from Islamizing sciences.

The academic concern of scholars of contemporary Islamic Studies can be illustrated through the perspective of the socio-anthropological theory of Great Tradition and Little Tradition and through history (Continuity and Change). This proposes that the social, economic, cultural, scientific and legal changes occurring in the Islamic world which interacts with the non-Islamic international world, always involve an intensive dialectic process between the great tradition -the realm of thoughts, concepts, doctrines, ideas, theories and beliefs, and the little tradition- the realm of practical application of these theories, concepts, ideas and beliefs in real life in a certain culture and historical period. Change will occur when a new tradition comes along that has a bigger strength and force compared to the academic tradition that was established before it. If the new tradition has a smaller force compared to that of the older academic tradition, then no change will occur and the status quo will be maintained. In religious studies, and particularly in Islamic studies, changes do occur, so that a change will not immediately cut off from the older scientific tradition that existed before it. This is the strong point and also the complexity of Islamic studies. There is still a continuity that carries over from the older academic traditions even though a new paradigm has emerged. As such the process of continuity and change can still be seen in religious studies (see the diagram below). Observers of Islamic studies need to master the theoretical models developed by scholars and observe the differences in patterns between one historical period and the next.

${ }^{12}$ The term "humanistic" is very popular now as a "counter theory" to "positivistic" tendencies in the philosophy of science. This paradigm shift in the philosophy of science has spread everywhere, to the point that there is even a book entitled Humanizing the Classroom by John P. Miller. Without exception, this discourse has also entered Islamic Studies. 


\section{ISLAMIC STUDIES/DIRASAH ISLAMIYAH \\ FROM THE PERSPECTIVE OF SOCIAL AND HISTORICAL THEORY}

\section{GREAT TRADITION}

- Studies of Shari'ah theories

- Studies of Tasawuf theories

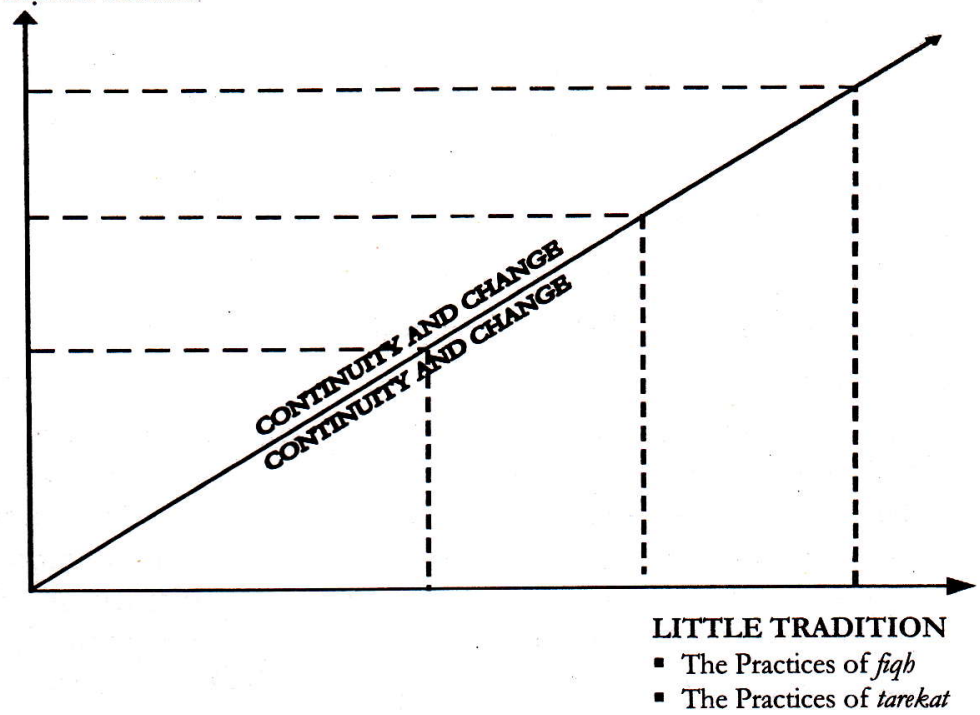

C. "The Philosophy of Science" in Islamic Studies: the Forgotten Analytical Tool.

Whatever science is compiled, conceptualized, written about systematically then communicated, taught and distributed orally and in writing cannot be without a philosophical paradigm. The basic assumptions of a scholar go along with the method (process and procedures) he or she follows, ${ }^{13}$ the approach goes along with the theoretical framework (the way of thinking) that is used. The role of logic, the measure of the scientific validity, the basic principles, and the relation

${ }^{13}$ For example these include the deductive method qiyas mantiqy for the field of aqidah, analogy qiyas fiqby for the field of Shari'ah, and the process of falsification (ta'arud al'-adillab) and verification (tabqiq). 
between subject and object ${ }^{14}$ are several of the main factors connected with the fundamental structure of an academic construction. This is without exception for natural sciences, social sciences, humanities, religious studies and also Islamic studies. Therefore, there is not one scientific discipline -especially one that has been systematized in such a way- that does not have a fundamental structure that can direct and set in motion the theoretical framework as well as guide the direction of research and further developments. The fundamental structure which is the foundation, background and stimulus for scientific activities is what is meant by the philosophy of science in this paper.

In discussing the realm of scientific philosophy, Harold I. Brown wrote the following:

Most scientific research consists, in this view of a continuing attempt to interpret nature in terms of a presupposed theoretical framework. This framework plays a fundamental role in determining what problems must be solved and what are to count as solutions to these problems; the most important events in the history of science are revolutions which change the framework. Rather than observations providing the independent data against which we test our theories, fundamental theories play a crucial role in determining what is observed, and the significance of observational data is changed when a scientific revolution takes place. Perhaps the most important theme of the new philosophy of science is its emphasis on continuing research, rather than accepted result, as the core of science. As a result, analysis of the logical structure of completed theories is of much less interest than attempting to understand the rational basis of scientific discovery and theory change. ${ }^{15}$

Harold I. Brown is essentially saying that a large part of scientific research consists of continual efforts to interpret and understand the complexities of nature (in this paper the writer has developed this further

${ }^{14}$ For further explanation see M. Amin Abdullah, “al-Ta'wil al-'Ilmi: Kearah Perubahan Paradigma Penafsiran Kitab Suci" in M. Amin Abdullah et al., (Ed.) Tafsir Baru Studi Islam dalam Era Multikultural (Yogyakarta: IAIN Sunan Kalijaga- Kurnia Kalam Semesta, 2000), pp. 1-34.

${ }^{15}$ As a comparison see Harold L. Brown, Perception, Theory and Commitment. The New Pbilosopby of Science (Chicago and London: The University of Chicago Press, 1977), pp. 911 (the italic is mine). In the field of humanities and social sciences, see Steve Fuller, Social Epistemology (Bloomington and Indianapolis: Indiana University Press, 1988). 
into society, humanity, religiosity and Islamic studies) through a theoretical framework, which was compiled earlier by other scholars/researchers. This theoretical working framework plays a very large role in determining what problems must be solved and what factors can be considered as solutions to that problem. The majority of important events noted in the history of science are radical discoveries or revolutions that were able to change the theoretical paradigms compiled by scholars before them. It is not that research and observation presents free data and through that data we can test our theories, rather the fundamental theories play a very meaningful role in determining the meaning of the data that is being researched. Moreover, in reality in the field, the significance of the data collected will change in meaning when a scientific revolution occurs. It may happen that the most important theme in the new philosophy of science emphasizes continual research and not the results that have already been accepted as the main core of scientific activity. As a result, analysis of the logical structure of the established and perfected theories may no longer be so interesting compared to efforts to understand the bases of rationality, scientific discovery and paradigm change. ${ }^{16}$

From the perspective of the philosophy of science, the theoretical framework is crucial and occupies a vital position in realm of scientific work because it is there that the basis of scientific rationality is located. Not only that, the direction and depth of academic analysis can also be traced and monitored from the theoretical framework used. As such, it is the task of observers, practitioners and teachers of Islamic Studies to respond to and re-formulate the philosophy of science in the realm of Islamic Studies. If Islamic studies is a standard scientific construct, compiled and formulated by scholars of religion, Islamic scholars, fuqah $\bar{a}$, mutakallimūn, mutasawwifün, mufassirūn, mubaddithün, and in previous eras was astute in facing the human and religious challenges of the time like other scientific constructs, then there is no responsible reason to avoid discovery, discussion and struggle with study of the philosophy of

${ }^{16}$ In the perspective of post positivistic philosophy of science, statements that studies of the al Qur'an are already "ripe" are considered of little interest because they close off the possibility of research about the rational bases that form the background of those formulas or academic religious argumentations. 
science. $^{17}$

Quite frankly I am personally doubtful of whether all lecturers teaching Islamic studies at UIN (the State Islamic University), IAIN (the State Institute of Islamic Studies) or STAIN (the State College for Islamic Studies) understand this most fundamental issue very well. They may be teaching branches of Islamic Studies (Dirasat Islamiyyab), that are very detailed, but in isolation without really understanding the basic assumptions and theoretical framework used by that scientific construct or their implications and consequences for social-religious practice. They may not be able to make comparisons between the epistemological systems of Islamic religious thought or critique the scientific constructs they teach in order to develop them further. We also must test their ability to connect basic assumptions, theoretical frameworks, paradigms, methods, approaches as well as the epistemology of one scientific discipline with those of another scientific discipline to expand the horizons and scope of scientific analysis.

This is even more crucial if we also consider discussions in the philosophy of science in the post-positivistic era. In the post-positivistic era there is not one scientific construct in any realm - including the realm of religion - which is free from, and independent of the cultural, social and even socio-political issues behind their emergence, that work as a scientific paradigm. As such, in the current era, the philosophy of science cannot stand alone. It needs to be discussed along with the sociology of science. ${ }^{18}$ If there is no interaction or dialogue between these two, then Muhammed Arkoun's comment, about there being symptoms of a sacrality in religious thinking (Taqdis al-afkār al-diniyyab) in the Muslim environment, among ordinary people, social and religious activists, teachers/lecturers of Islamic

${ }^{17}$ For further reference see M. Amin Abdullah, "Preliminary Remarks on the Philosophy of Islamic Religious Science" al-jami'ab, No.61, TH. 1998, pp. 1-26; also "Kajian Ilmu Kalam di IAIN Menyongsong Perguliran Paradigma Keilmuan Keislaman Pada Era Milenium Ketiga" al-jämi'ah, No. 65/VI/2001. pp 78-101.

${ }^{18}$ Gregory Baum, Truth Beyond Relativisme: Karl Mannheim's Sociology of Knowledge. Translated into Indonesian by Achmad Mustajib (et al) with the title Agama dalam Bayangbayang Relativisme: Sebuah Analisis Sosiologi Pengetabuan Karl Mannbeim tentang Sintesa Kebenaran Historis-Normatif (Yogyakarta: PT. Tiara Wacana, 1999). 
Studies at UIN (the State Islamic University), IAIN (the State Institute of Islamic Studies), STAIN (the State College for Islamic Studies) and lecturers of religion at other tertiary institutions, can be understood. As a result, merely because of differences in theoretical frameworks, methodology, epistemology as well as variations in the literature used, Muslim leaders too easily declare their fellows to be apostates, infidels or otherwise affirm them. In other words, the phenomena of taqdis al-afkear aldiniyyah can more easily ignite the emotions of individuals or groups compared with its ability to foster integrity and a mature outlook within them.

In the reality in the field, it is rather difficult to answer why lecturers who teach Islamic Studies or 'Ulum al-din (Kalam/'Aqidah, Fiqh, Falsafah, Nahwu, Baläghah, 'Ulum al-Qur'ān, 'Uhìm al Hadith, Tasawuf, and also Religious Education and Propagation) at UIN/IAIN/STAIN (the State Islamic University/the State Institute of Islamic Studies/the State College for Islamic Studies) and other private and public higher education institutions are not really interested in understanding the basic assumptions, theoretical frameworks, paradigms, epistemologies, and fundamental structures that supported the construction of these sciences by their pioneers hundreds of years ago. One reason may be because there has not been much research or many books compiled in this field of inquiry. Or the answer from IAIN (State Institute of Islamic Studies) that may be more common is that discussions of the philosophy and epistemology of science in Islamic Studies or 'Ulum al-din are deliberately avoided, because this realm considered "conceptual - philosophical". This is more complex, more complicated, and more based on discussion than the teaching of the practical sciences that are already "established" which only need memorizing and applying to daily life. It is no secret that philosophical discussions in general, especially those on the philosophy of science are strongly avoided by the fuqab $\vec{a}$, and mutakallimun $n^{19}$ because they

${ }^{19}$ Muhammad 'Abid al-Jabiry stated that for almost 400 years (from year $150 \mathrm{H}$ until $550 \mathrm{H}$ ) all of the Muslim intellectual property written in Arabic (i.e. the yellow book) attacked and comered philosophy, in terms of method, epistemology and discipline. For further reference see Bunyab al-'Aql al-'Araby: Dirasab taḅlitiyyah naqdiyyab li nudümi al- 
consider that this will confuse the followers.

Thus automatically and naturally we have experienced a drying out, and even drying up of the source of dynamism, which is the heart of and pre-requisite for the development of knowledge in Islamic Studies in facing new challenges that arise as a direct result of the developing scope of human experience. In turn, this has resulted in the isolation of Islamic Studies and 'Ulum al-din from the social and cultural sciences and made it difficult to develop Islamic Studies or Diräsät Islamiyyab itself. ${ }^{20}$

I would like to put forward a small illustration from the field here. When I introduced the need to search for, observe and develop method, approach, and theoretical framework, and even the importance of prior research for the development of Islamic knowledge (contribution to knowledge) to students of the Masters (S2) and Doctoral (S3) program at IAIN (State Institute of Islamic Studies) they felt that these issues were very alien to them. Almost all alumni of the Adab, Dakwab, Syariah, Tarbiyah and Ushuluddin faculties, including those managed by IAIN (the State Institute of Islamic Studies), STAIN (the State College for Islamic Studies) and PTAIS (Private Islamic Higher Education) let alone academic institutions managed by the community and Islamic boarding schools stated that they had never been introduced to such concepts by their lecturers in their previous undergraduate degrees. They knew only a little about these terms and they admitted that their knowledge was most insufficient - because even though it may have been introduced, this was done through the Research Methods lectures in their respective faculties. Nevertheless, the research methodologies they were taught were very practical and limited only to the social sciences. They were not so connected with the issues of humanities, let alone with the philosophy of science and the sociology of religious knowledge. Ideally every lecturer who is a graduate of a Masters, or Doctorate program who teaches Islamic Studies and 'Ulum al-din needs to devote a significant amount of time to

ma'rifah fi al-thaqäfab al-'Arabiyyah (Beirut: Markaz Dirāsah al-Wihdah al-Arabiyyah, 1990), pp. 497-498.

${ }^{20}$ Fazlur Rahman, Islam dan Modernity, p. 157-158. Also Hẹasan Hanāfi, "Fi al fikr alIslāmy al-Mu'āsir" in his book Dirasat Islamiyyah (Qahira: Maktabah al-Anjilo alMișriyyah), p. 345-456. 
explaining the philosophy of science and epistemology within their branch of Islamic Studies, how it operates in the field of research as well as the development in their respective fields. Conveying this information should not wait to be given in lectures on research methodology, which are often given too far off the point and the vocal focus required by each scientific discipline within Islamic Studies.

This analysis underlines that an essential prerequisite for developing the postgraduate studies program, both at the masters and doctoral levels, is the need for interaction and intensive dialogue with the philosophy of science, and how far scholars of Islamic Studies are able to dialogue and touch base with other academic disciplines, especially those in social studies and humanities like sociology, history, philosophy, literary criticism, linguistics, hermeneutics, cultural studies, psychology, anthropology and so on. $^{21}$ (see the diagram on expanding the academic horizons of Islamic Studies).

\section{Developing Islamic Studies in the Postgraduate Program: Expanding Horizons Through the Spider Web Method.}

The diagram below illustrates a spider web connection of theoanthropocentric-integralistic knowledge. We see that there is such a wide scope of views and horizons in the methods and approaches of integralistic Islamic studies. And at the same time they are functional in both the traditional and modern sector, hence their mastery can support life in the information-globalization era. Besides that it also presents a form that is competent of handling and analyzing issues relevant to humanity and religion in the modern and post-modern era by introducing various new approaches contributed by the natural sciences, social sciences, contemporary humanities and religious studies. Above all, each step that is taken is always supported by an objective and firm ethical-

${ }^{21}$ Fazlur Rahman, "Approaches to Islam in Religious Studies: Review Essay" in Richard C. Martin (Ed.), Approaches to Islam in Religious Studies, p. 196. Also Mohammed Arkoun. "Taṭbiq 'ulūm al-Insān wa al-Mujtama' 'alä Dirāsat al-Islām" in his book al-Fikr al-Islamm: Qira'ab Tlmiyyah, translated by Hashim Șālih (Beirut: Markaz al-Inma' al-Qaumi, 1987), pp. 87-112. 
moral religious base, because the al-Qur'an and al-Sunnah which are interpreted in a new way (hermeneutically) remain the bases for the outlook on life (weltanschaunng) of human religiosity, which is united in one academic and religious breath. All of this is designed for the prosperity of all humanity, irrespective of race, religion, ethnicity or political affiliation.

HORIZONS OF A SPIDER WEB OF ISLAMIC STUDIES IN AN ERA OF MULTICULTURAL AND MULTIRELIGIOSITY

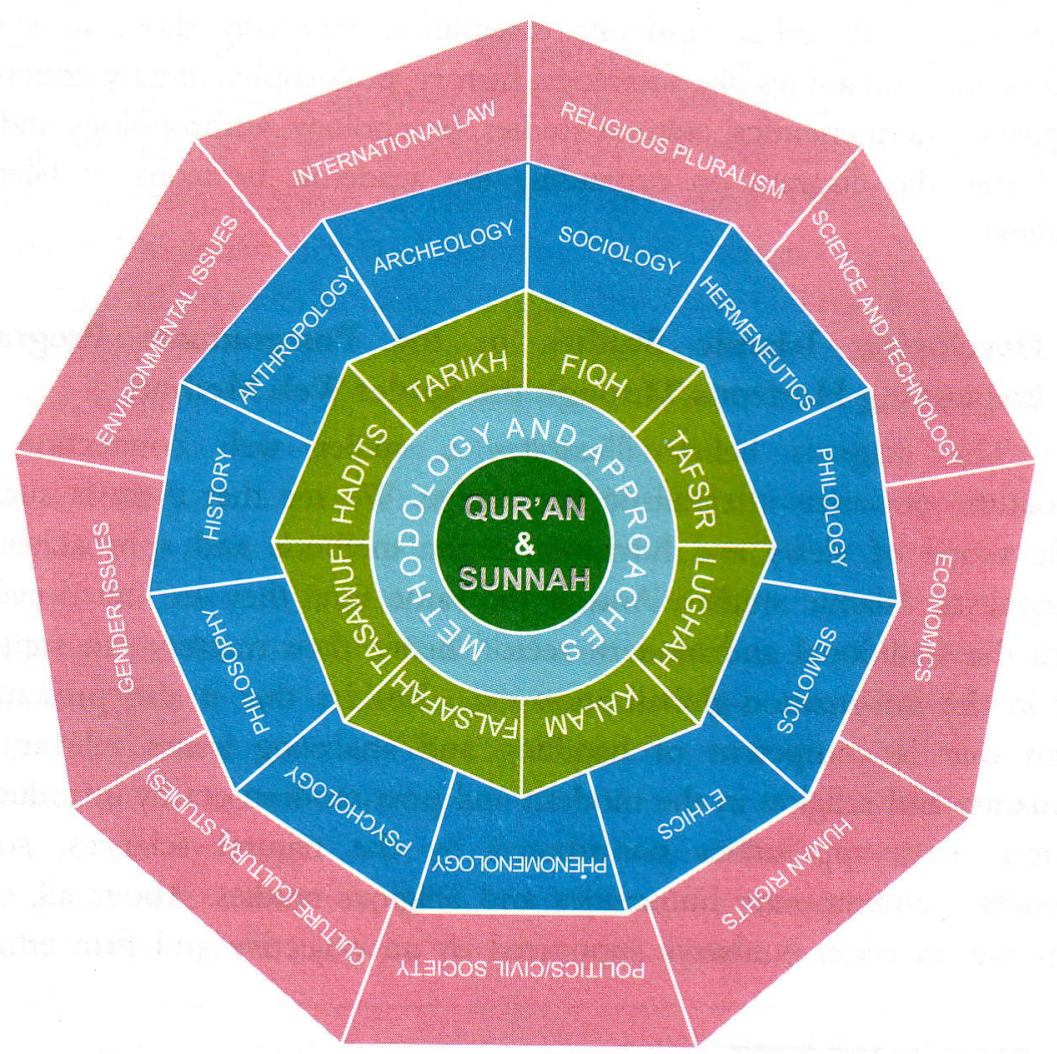

Under the current conditions, academic activity at tertiary institutions of religion, especially at IAIN (the State Institute of Islamic Studies) and STAIN (the State College for Islamic Studies) throughout 
Indonesia is only focused on and limited to the first and second layers of the circle (Kalam, Falsafah, Tasawnuf, Hadith, Tarikh, Fiqh, Tafsir, Lughab). And even then it is only limited to the approaches from the classic humanities. $^{22}$ IAIN (the State Institute of Islamic Studies) and STAIN (the State College for Islamic Studies) in general are not yet able to enter into discussions on social studies and contemporary humanities and combine Islamic studies with the disciplines pictured in the third circle (Anthropology, Sociology, Psychology, Philosophy and the various approaches they offer). As a result there is an unabridged chasm in academic outlook between the classical/traditional Islamic sciences and the newer Islamic sciences that are taking advantage of analyses of social studies and contemporary humanities. ${ }^{23}$

This imbalance in intellectual outlook has a significant impact on the dynamics of social and religious life in Indonesian society, given that many of the alumni of IAIN/STAIN (the State Institute of Islamic Studies/the State College for Islamic Studies) go on to become community leaders wherever they may be. Furthermore, this imbalance in intellectual outlook is felt even more sharply by students and alumni of general higher education institutions, especially those who take the exact sciences. Efforts to bridge this chasm of outlook are being made in the Masters Programs, but not all IAIN (the State Institute of Islamic Studies) are able to offer this. This is because of a limitation in terms of teachers who understand

${ }^{22}$ A group of Islamic sciences usually called "traditional Islamic sciences" are still taught until today throughout the modern Arab world and in Muslim nations. Quoting Ibn Khaldun, Ibrahim M. Abu Rābi' portrayed the actors and practitioners of the traditional Islamic sciences as "dull or at any rate not try[ing] to be dull". Ibid., h. 29. See also the diagram of Period One (Pre-1950) in the Development of Connections between Islamic Studies and Other Related Disciplines.

23Postcolonial Muslim scholars including Muhammed Arkoun, Muhammad 'Ábid alJabiri, Nașr Hamid Abu Zaid, 'Abdullāhi Aḥmed al-Na'ỉm, Muhammad Shahrūr, Abdul Karim Soroush as well as Hassan Hanāfi, Seyyed Hossein Nasr, Fazlur Rahman and others have utilized these new analytical tools. Translations of their works into Indonesian have started to become widely available in Indonesia, and many are read by students of UIN/IAIN/STAIN (State Islamic University/State Institute of Islamic Studies/State College for Islamic Studies) other general higher education institutions as well as Islamic study groups. See also the diagram of Period Two of the Islamic Sciences on page 21 of this paper. 
and have mastered the Islamic sciences and also the social sciences and contemporary humanities. However, even those who can offer it will come up against many difficulties, because apart from limitations in the human resources available, the mind set of undergraduate students is so rigid in studying normative texts without touching on the views from science and technology, social sciences or humanities. ${ }^{24}$

Issues of society, politics, economics, religious pluralism, military, gender, the environment, social studies and post modern contemporary humanities as well as the methods and approaches that go with them, as pictured in the fourth layer, are almost not touched by Islamic studies in Indonesia, especially at IAIN/STAIN (the State Institute of Islamic Studies/the State College for Islamic Studies). Statements like "to be religious today is to be inter religious" still sound absurd, unthinkable, even out of the question for the traditions of the layer two sciences, yet the globalization - information era forces modern religious people to think this way. There is some truth in the statement by Ebrahim Moosa, as quoted at the beginning of this article, where in the introduction to Fazlur Rahman's book, Revival and Reform in Islam: A Study of Islamic Fundamentalism, he states:

... having raised the question of international relations, politics, and economics, that does not mean that scholars of religion must become economists or political scientists. However, the study of religion will suffer if its insights do not take cognizance of how the discourses of politics, economics, and culture impact on the performance of religion and vice-versa. ${ }^{25}$

This can be interpreted as meaning that after we express various issues related to international relations, politics and economics, this doesn't mean that academics and religious scholars (including Islamic scholars) must become economists or political scientists. Nevertheless, religious studies (including Islamic studies) will experience great difficulties - if not

${ }^{24}$ For further reference see M. Amin Abdullah, "Muhammed Arkoun: Perintis Penerapan Teori Ilmu-Ilmu Sosial Era Post-Positivis Dalam Studi Pemikiran Keislaman", in Mohammed Arkoun, Membongkar Wacana Hegemonic dalam Islam dan Post Modernisme, translated by Mashur Abadi (Surabaya: Al-Fikr, 1992), pp. iii-xvi.

${ }^{25}$ Ebrahim Moosa, "Introduction", in Fazlur Rahman, Revival and Reform in Islam: $A$ Study of Islamic Fundamentalism (Oxford: Oneworld Publication, 2000), p. 28. 
to say will suffer - if its outlook is not aware of and does not consider how the discourse developing in politics, economics and culture influence the appearance and behaviour of religion and vice versa.

In the future this difficulty will become even harder with the reality in the field that religious studies (read: Islamic studies) are really not designed to be integrated with technology and sciences which give priority to skills for living more widely, -- not only to fulfill governmental i.e. Department of Religion bureaucratic requirements. Science and technology is separated far from the core of the science of texts ( $\mathrm{ilm}$ qauliyyab), and these stand alone, without any contact or interaction. In fact it often occurs that Islamic studies as it is currently taught almost does not equip graduates with the skills needed to guard, foster, supervise and control the morality and piety of the public. This phenomenon is certainly not advantageous for the students in terms of the wider life of the nation because from the beginning it has deviated from the core pattern of teaching the al-Qur'an, which always integrated general sciences and religious studies. Is not al-ulum al-diniyyah, al-ulum al-kauniyyah, al-ulum alinsäniyyah, al-ulum al-tärikhiyyah, and al-ulum al-falsafiyyah-al-akbläizyah, united in the vocabulary of the al-Qur'an so that it needs to be investigated and developed in an integrated and proportional way? ${ }^{26}$

If we map out the history of developments in Islamic Studies in Religious Tertiary Institutions in Indonesia, particularly in the Undergraduate and Masters programs, there are at least four periods that have passed. The first period was pre-1950s. The second period was between 1951 and 1975, followed by the third period between 1976 and 1995, and finally followed by the fourth period, which commenced in 1996 and still continues looking for a more mature form. The methodological struggle between the four periods can be pictured as follows:

${ }^{26}$ The concept of integrating general sciences and religious studies through the Bayani, 'Irfani and Burbani epistemological perspectives can be checked further in the book listed in footnote no. 14 of this paper. This can also be compared with the methodological struggle of the new Islamic sciences of the contemporary era in Period Four on page 21 of this article. 
DEVELOPMENTS IN THE CONNECTION BETWEEN ISLAMIC STUDIES AND OTHER RELATED DISCIPLINES IN RELIGIOUS HIGHER EDUCATION INSTITUTIONS

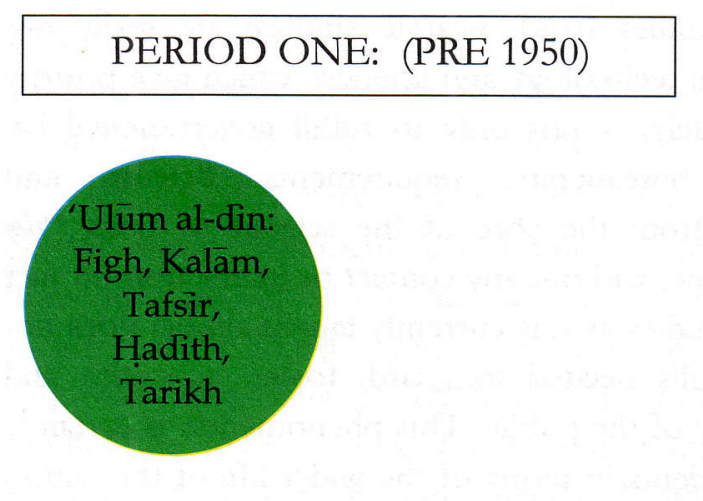

PERIOD TWO: (1951-1975)

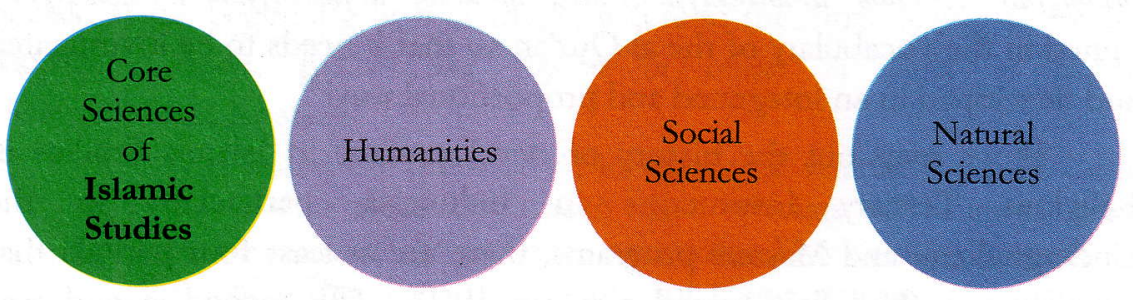

PERIOD THREE: (1976-1995)

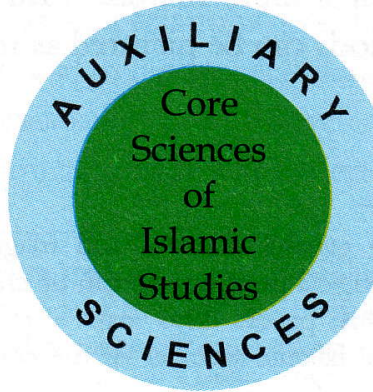


PERIOD FOUR: (1996-present)

Can evolve in accordance with research finding and development in society

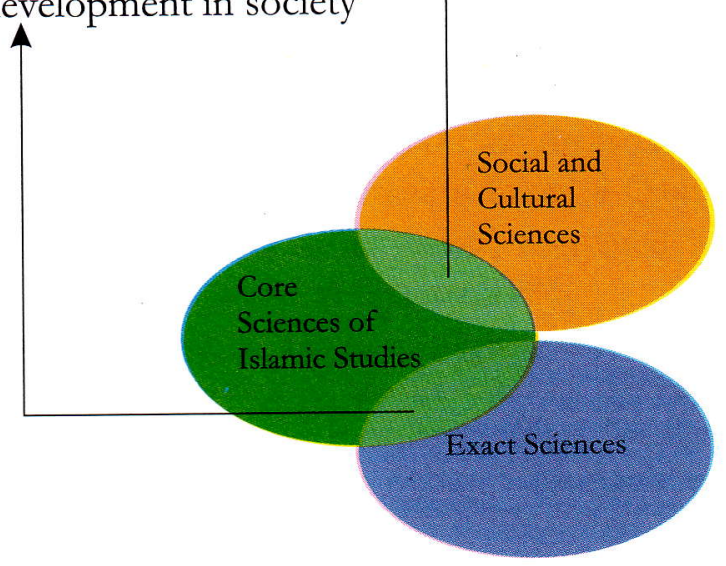

E. Concluding Remarks: Academic Development in the Postgraduate Program is a Path of No Return.

Given the complexity of developments within "Islam" in Indonesia in connection to the international world as well as the interaction between Islamic Studies and other sciences pictured in the diagram of the horizons of contemporary Islamic Studies, the function of Postgraduate Education in Islamic Studies becomes strategic and very important, because it is from here that the potential teaching staff of UIN/IAIN/STAIN (the State Islamic University/the State Institute of Islamic Studies/the State College for Islamic Studies) will come.

Not negotiable in efforts to develop the academic quality of postgraduate students is the mastery of and need for the patterns, methods (processes and procedures), approaches, and theoretical frameworks (ways of thinking) offered by a variety of academic disciplines, especially the philosophy of religious studies. 
In the future the postgraduate programs of UIN/IAIN/STAIN (the State Islamic University/the State Institute of Islamic Studies/the State College for Islamic Studies) will become academic centers of Islamic Humanities and Islamic Social Sciences respected in Indonesia for their academic reputation. There is no point of return in the development of the postgraduate academic program. 


\section{BIBLIOGRAPHY}

Abdullah, M. Amin, "Preliminary Remarks on the Philosophy of Islamic Religious Science”, al-Jami'ah, No. 61 Th. 1998.

"Kajian Ilmu Kalam di IAIN Menyongsong Perguliran Paradigma Keilmuan Keislaman Pada Era Millenium Ketiga", alJämi'ah, No. 65/VI/2000.

Arkoun, Muhammed, Tärikhiyyah al-Fikr al-'Araby al-Islämy, translated by Hashim Șălih, Lebanon: Markaz al-Inma' al-Qaumy, 1986. , al-Isläm: al-Akhläq wa al-Siyäsah, translated by Hashim Șhalih, Beirut: Markaz al-Inma' al-Qaumy, 1986.

Baum, Gregory, Agama dalam Bayang-bayang Relativisme: Sebuab Analisis Sosiologi Pengetabuan Karl Manbeim tentang Sintesa Kebenaran Historisnormatif (Truth Beyond Relativism: Karl Manheim's Sociology of Knowledge), translated by Achmad Murtajib et al., Yogyakarta : PT. Tiara Wacana, 1999.

Brown, Harold I., Perception, Theory and Commitment: The New Philosophy of Science, Chicago and London: The University of Chicago Press, 1997.

Esack, Farid, al-Qur'an, Liberalism, Pluralisme: Membebaskan yang Tertindas, Bandung: Mizan, 2001. (Original title: Qur'ān, Liberation \& Pluralism: An Islamic Perspective of Interreligious Solidarity Against Oppression.)

Fuller, Steve, Social Epistemology, Bloomington and Indianapolis: Indiana University Press, 1988.

Hanāafi, Hasan, Dirāast Islämiyyah, Qahira: Maktabah al-Anjilo al-Mișriyah. Al-Jabiry, Muhammad 'Abid, Bunyah al-'Aql al-'Araby: Dirāsab Tablitiyyah Naqdīab li Nužumi al-Ma'rifah fi al-Thaqafah al-'Arabiyah, Beirut: Markaz Dirāsah al-Wiḥdah al-'Arabiyah, 1990.

Takuin al-'Aql al-'Araby, Beirut: Markaz al-Thaqafy al- 'Araby, 1990.

Kuhn, Thomas S., The Structure of Scientific Revolutions, Chicago: The University of Chicago Press, 1970.

Kurzman, Charles (Ed.), Liberal Islam: A Sourcebook, New York: Oxford University Press, 1988. 
Martin, Richard C. (Ed.), Approaches to Islam in Religious Studies, Tucson: The University of Arizona Press, 1985. Also Indonesian translation, Pendekatan Kajian Islam dalam Studi Agama, translated by Zakiyuddin Baidhawy, Surakarta: Muhammadiyah University Press, 2001.

Mernisi, Fațima, Beyond the Veil: Male-Female Dynamics in the Modern Muslim Society, Bloomington: Indiana University Press, 1987.

Mudzhar, M. Atho', "Social History Approach to Islamic Law", al-Jämi'ah, No. 61 Th. 1988.

al-Na'im, Abdullāhi Ahmed, Toward an Islamic Reformation: Civil Liberties, Human Rights and International Law, New York: Syracuse University Press, 1990.

Rahman, Fazlur, Islam and Modernity: Transformation of an Intellectual Tradition, Chicago and London: The University of Chicago Press, 1982.

Shahrour, Muhammad, al-Kitāb, wa al-Qur'an: Qira'ah Mu'așirah, Dimasq, 1990.

Zaid, Nașr Hamid Abu, Naqd al-Khitâb al-Dīni, Qahira: Sina li al-Nasry, 1994.

Tekstualitas al-Qur'ä: Kritik terbadap Ulumul Qur'än (Mafbüm alNaș: Dirāsah fi 'Uhīm al-Qur'an), transl. Khoiron Nahdliyyin, Yogyakarta: LKiS, 2001. 